Vera Majstorović Univerzitet u Beogradu

Filološki fakultet

Srbija

veramajstorovicc@gmail.com
DOI:https://doi.org/10.18485/slovenika.2019.5.1.4

UDK: 811.163.41:811.163.6

Stručni članak

\title{
Ka rečniku srpsko-slovenačkih lažnih prijatelja
}

Sažetak

Jezici koji su deo iste jezičke porodice, kakvi su srpski i slovenački, genetski su srodni i odlikuju ih brojne međujezičke podudarnosti. Komparativnokontrastivna lingvistička istraživanja bave se sličnostima i razlikama na morfološkoj, fonetskoj, fonološkoj, sintaksičkoj i leksičkoj ravni. Nedovoljno istražena pojava tzv. lažnih prijatelja dvaju jezika $u$ kontaktu biva $u$ radu definisana, analizirana i ilustrovana konkretnim primerima. Rad ima za cilj da podstakne na nova istraživanja i potencijalno leksikografsko kompletiranje građe srpskih i slovenačkih međujezičkih homonima.

Ključne reči: međujezička homonimija, lažni prijatelji, srpski jezik, slovenački jezik

\section{Šta (ni)je međujezička homonimija?}

Homonime, „dvije ili više riječi različita značenja i podrijetla koje imaju isti zvuk ili grafiju“ (Simeon 1969, 487), prepoznajemo kao reči koje su deo leksike jednog jezika. No dešava se da se reč istog oblika nađe unutar leksika dvaju različitih jezika, dok joj je značenje posve različito. Ova pojava se naziva međujezičkom homonimijom, i ona stvara zabunu i poteškoću prilikom učenja jezika, prevođenja i govorenja stranog jezika. To se dešava zbog „refleksnog prepoznavanja leksičkih oblika te podrazumijevanja da i u materinskom jeziku i u stranom jeziku slične ili iste riječi imaju isto značenje“ (Lewis 2008, 173).

Termin lažni prijatelji prvi put se javlja krajem 30-ih godina XX veka (Kœssler et al 1928), na primeru međujezičke homonimije između francuskog i engleskog jezika. Iako je ovakva, metaforička upotreba termina netipična u lingvističkom diskursu, vremenom je 
prihvaćena, najpre od strane prevodilaca i teoretičara prevođenja, verovatno zbog toga što ni termin međujezički homonimi nije idealan, budući da je uži od onoga što se pod njim podrazumeva (Lewis 2008, 177).

Međujezička kontrastivna leksikološka istraživanja nalaze najviše prostora za obradu lažnih prijatelja. Ipak, istraživanja nema onoliko koliko je očekivano da ih bude, jer se istraživači susreću sa različitim problemima. Pre svega, ne postoje zajednički kriterijumi $\mathrm{u}$ vezi s terminološkim određenjem ove pojave, niti su jasno kategorisani uzroci njenog nastanka. Ne postoje ni jasne podele međujezičkih homonima, već samo grube podele koje se tiču (ne)apsolutnog značenjskog i / ili grafemskog (ne)preklapanja. Takođe, nije jasno odgovoreno ni na pitanje između kojih se to jezika može javiti međujezička homonimija - da li samo između jezika u kontaktu ili i prilikom pozajmljivanja reči, dakle, i među nesrodnim jezicima, te pukom slučajnošću. Bez obzira na izbor kriterijuma, leksikografi se slažu sa činjenicom da međujezičke homonime nije lako zabeležiti, a još ih je teže leksikografski obraditi.

Svakako, pojava lažnih prijatelja je najzanimljivija metodičarima nastave stranih jezika, teoretičarima prevođenja, prevodiocima i leksikografima (Đukanović 2007, 478), i svi oni problemu pristupaju s pozicija i metoda vlastitih naučnih disciplina. Najveći broj radova na ovu temu bavi se pojavom međujezičke homonimije na primeru jezika istih jezičkih porodica. U ovom radu će biti razmatrani međujezički homonimi dvaju južnoslovenskih jezika u kontaktu - srpskog i slovenačkog.

\section{Srpski i slovenački u kontaktu}

Srpski i slovenački vekovima imaju značajne dodire ne samo na jezičkom nego i na istorijskom, odnosno kulturološkom planu. Kontakt dvaju jezika seže od zajedničkog prapretka, praslovenskog jezika. U 9. veku dolazi do izvesnih preklapanja prilikom stvaranja staroslovenskog jezika ${ }^{1}$, a isto se dešava i u doba ilirizma ${ }^{2}$, vremena $u$

\footnotetext{
${ }^{1}$ „Određene stilske i jezičke karakteristike svedoče o postojanju, mada samo posredne veze sa starocrkvenoslovenskom kniževnošću. Naime, delovanje solunske braće, Ćirila i Metodija, kao i slovenska akcija pokrštavanja uopšte nije predstavljala snažniji impuls: dotakla se samo krajnjeg severoistočnog ruba slovenačke teritorije.“ (Mitrović 1995, 13).

${ }^{2}$ Ilirizam je književni i kulturni društveno-politički pokret, nastao u Hrvatskoj 30-ih godina 19. veka, koji je imao za cilj okupljanje svih južnih Slovena oko zajedničkog jezika i pravopisa. U Sloveniji je bilo intelektualaca (Stanko Vraz) koji su prihvatali navedene ideje (Rečnik književnih termina 1985, 261-262 ).
} 
kome se slovenački intelektualci odupiru germanizaciji slovenačkog jezika i okreću južnoslovenskim jezičkim rođacima. Najznačajniji je kontakt u vreme jugoslovenskog suživota, kada se srpskohrvatski jezik uči u slovenačkim školama, a popularna kultura (stripovi, časopisi, literatura, filmovi, muzika i dr.) ulazi u sve pore jugoslovenskog društva. Danas, Srbija i Slovenija imaju ekonomsku saradnju, u Srbiji aktivno posluje više stotina slovenačkih firmi, a ekonomska migracija Srba u Sloveniju ne jenjava.

S obzirom na to da su slovenački i srpski jezik veoma bliski, komunikacija se lako uspostavlja. U takvoj, jednostavnoj komunikaciji, lažni prijatelji dolaze do izražaja, i tada oni bivaju simpatični. Ipak, zbog visokog razumevanja srpskohrvatskog jezika, mnogi slovenački govornici tvrde da srpski jezik poznaju sasvim dobro i znaju se latiti kompleksnog posla, kakvo je prevođenje. Greške koje nastaju tom prilikom bivaju morfološke, fonetske, fonološke, leksičke i sintaksičke prirode. Međujezički homonimi se u ovoj situaciji vidno ispoljavaju, i to ne samo pravi homonimi (homofoni i homografi), već i oni nepotpuni, u slučajevima kada se lekseme vrlo malo razlikuju, što ilustruju konkretni primeri predstavljeni u nastavku ovog rada.

\section{Srpsko-slovenački međujezčki homografi / homofoni}

Međujezičkom homonimijom na primerima srpskog i slovenačkog jezika bavilo se malo autora. Janko Jurančič u udžbeniku slovenačkog jezika za srpske i hrvatske govornike (Jurančič 1971) zbraja ukupno 268 međujezičkih homonima, stvarajući mini rečnik srpskohrvatsko-slovenačkih lažnih prijatelja. Pre popisa odrednica, u kratkom uvodu, Jurančič primećuje: „Južni Sloveni, naime Slovenci, Hrvati, Srbi, Makedonci i Bugari, mogu jedni druge, kako bi rekao Vuk Karadžić, 'za nevolju' razumjeti, ali svaka riječ i svaka rečenica ipak neće biti potpuno jasna kad bi, na primjer, jedan Slovenac i jedan Srbin razgovarali svaki na svom jeziku. Manje ili veće nejasnosti i kriva razumjevanja dolazili bi odatle što svaki od južnoslovenskih jezika, pored svima zajedničkih riječi sa istim značenjem, ima i priličan broj riječi istih po obliku a različitih po značenju“ (Jurančič 1971, 29).

Nakon Jurančičevog popisa leksema, prvi sledeći kompleksniji popis javlja se u savremenom Slovenačko-srpskom i srpsko-slovenačkom rečniku Maje Đukanović i Vlada Đukanovića (Đukanović i dr. 2005). Unutar rečnika mapirani su i podvučeni međujezički homografi. U slovenačko-srpskom rečniku ima ih 260 (176 imenica, 53 glagola, 22 prideva, 1 zamenica i 8 priloga), dok ih je u srpsko-slove- 
načkom 176 (94 imenice, 23 prideva, 46 glagola, 10 priloga, 1 veznik i 2 zamenice). U najvećem broju slučajeva, predstavljeni homonimi pripadaju istoj vrsti reči u oba jezika, ali ima i onih koji pripadaju različitim vrstama reči (Đukanović i dr. 2011, 38).

U ovom delu rada tabelirano je 20 međujezičkih homografa - „leksema koje se pišu na isti način, ali se razlikuju značenjem " (Kristal 1988, 131), i homofona - „leksema koje se jednako izgovaraju, ali su im značenja različita" (Kristal 1988, 130), te njihovih prevoda na oba jezika. Prvo su navedene imenice, zatim glagoli, te pridevi, i na kraju one reči koje u dvama jezicima ne pripadaju istoj vrsti reči.

Međujezički

homograf: slovenačko-srpski:

srpsko-slovenački:

Imenice:

blago

čas

blagó -a $s$ roba; materijal, tkanina čàs -e $m$ vreme (u značenju trajanja), doba

družina družína-e ž porodica

grad grád -u -a $m$ zamak, tvrđava

krilo krílo -a s suknja

leto léto -a $s$ godina

mesto mésto -a $s$ grad

snaga snága -e ž čistoća

vilice vílice-lic $z ̌ m n$. Viljuška

zagrada zagráda -a ž pregrada

Glagoli:

brati

gojiti

bráti berem nedov. čitati

gojíti -im nedov. gajiti, negovati; uzgajati

igrati igráti -am nedov. igrati; glumiti; svirati

vaditi váditi -im nedov. vežbati

Pridevi:

ljudski

rumen

ljúdski -a -o prid. narodni rumén -a -o prid. žut

slovenski

slovénski -a -o prid. slovenački

Nepromenljive vrste reči:

ja já prisl. potvrdna rečca: da

gotovo gotóvo prisl. izvesno, svakako

ko ko vez. kad

naravno narávno prisl.pravo; direktno, otvoreno blâgo-e $s$ zaklad

čàs -a $m$ treutek, hip; (šolska) ura

drùžina-e ž tovaršija, družba

grâd -a $m$ mesto; gràd -a m toča

krílo -a $s$ perut (ptice); naročje

lèto-a $s$ poletje

mèsto -a $s$ kraj, prostor

snága -e ž moč

villica -e $z \check{z}$ čeljust

zâgrada-a ž oklepaj

bräti berem nesv. obirati

gòjiti se-im se nesv. rediti se

igrati -am nesvr. igrati, plesati

vàditi -im nesvr. jemati ven, jemati iz, vleči iz

ljùdski -a -o prid. človeški rùmen -a -o prid. crvenkast, ružičast slòvēnski -a -o prid. slovanski

jâ zam. ja gòtovo pril. konačno

kö zam. kdo, kdor

náravno rečca seveda

Tabela 1. Međujezički homografi i homofoni 
Prikazana tabela nudi samo osnovne oblike reči, i to one kod kojih se javlja maksimalno formalno podudaranje. One se u svom osnovnom značenju u potpunosti razlikuju, ali imenica krilo je, primera radi, višeznačna, te se neka njena značenja u oba jezika podudaraju, no ono pak koje pravi zabunu, gorenavedeno, ne poznaje semantičku podudarnost.

\section{Nepotpuni međujezički homonimi}

Kao što je do sada navedeno, „specifičnost srpsko-slovenačkih međujezičkih homonima ogleda se u tome što se javlja značajan broj reči koje su potpuno istovetne po formi. Sa druge strane postoji značajan broj reči u dva jezika koje su slične, ali ne sasvim iste po svom obliku“ (Đukanović i dr. 2011, 37). Dakle, lažnim prijateljima smatramo i sledeći leksički par: upokojen (leksema u srpskom jeziku) i upokojenec (leksema u slovenačkom jeziku), lekseme koje imaju potpuno različita značenja. Dok se srpska leksema odnosi na „pokojni, mrtvi, umrli“ (Rečnik srpskoga jezika 2011), slovenačka se odnosi na penzionera. Sledi tabela od 10 takvih, nepotpunih međujezičkih homonima, takođe u njihovom osnovnom obliku:

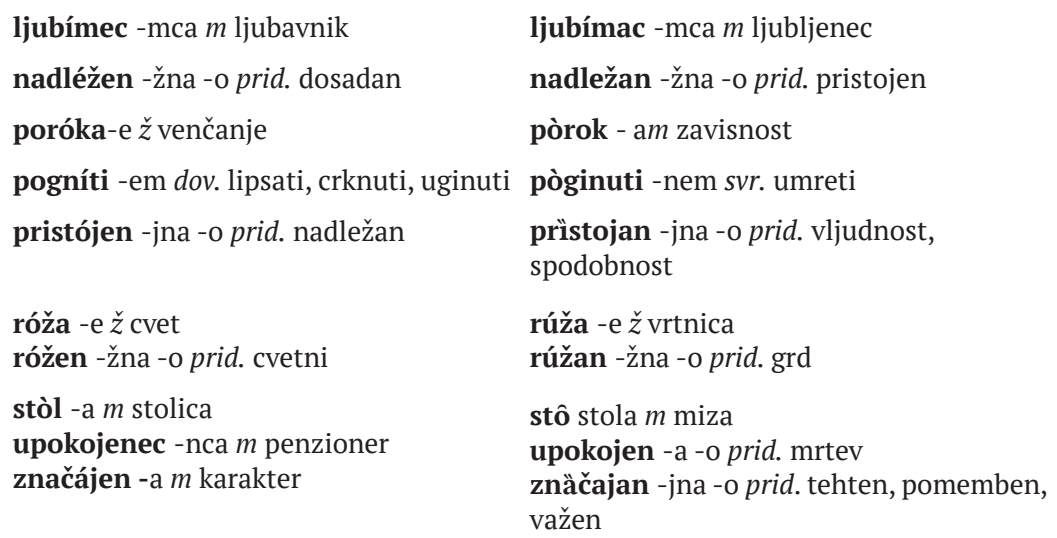




\section{Ostali međujezički homonimi}

Međujezičkim homonimima, pored navedenih, možemo smatrati i:

- lekseme koje imaju homonimične tvorbene osnove, ali različite tvorbene afikse;

- lekseme koje imaju značenjsku razlikovnost, a glasovno preklapanje u samo nekim oblicima;

- lekseme koje stvaraju konfuziju samo u određenom kontekstu;

- lekseme koje ne pripadaju književnom standard, već su u pitanju dijalektizmi, žargonizmi ili arhaizmi.

\section{Zaključak}

Međujezička homonimija dva srodna jezika obuhvata celovit sistem leksema. Rad ima za cilj da se suoči sa ovom, nedovoljno istraženom problematikom i da podstakne na razmišljanje o tome kako bi se moglo pristupiti izradi sveobuhvatnog rečnika srpsko-slovenačkih lažnih prijatelja. Mada je za takav čin potreban višegodišnji rad, krajnji cilj, poput kvalitetnijih prevoda, olakšanog istraživanja u uporednoj leksikologiji i lakšeg učenja stranog jezika, bio bi od neprocenjive vrednosti za struku.

Za kraj, sledi predlog za izradu odrednice u jednom takvom rečniku. Za stvaranje odrednice korišćeni su Slovenačko-srpski i srpsko-slovenački rečnik (Đukanović i dr. 2005), Slovar slovenskega knjižnega jezika (Slovar slovenskega knjižnega jezika 2012), Sinonimni slovar slovenskega jezika (Snoj i dr. 2016) i Rečnik srpskoga jezika (Rečnik srpskoga jezika 2011). Ovo rešenje je samo skica i na njemu bi trebalo još raditi, kako bi teorijsko i praktično objašnjenje odrednice bilo u potpunosti ispunjeno. 


\begin{tabular}{|c|c|c|c|c|}
\hline $\begin{array}{l}\text { Međujezički } \\
\text { homonim }\end{array}$ & $\begin{array}{l}\text { Prevod sa } \\
\text { slovenačkog } \\
\text { na srpski }\end{array}$ & $\begin{array}{l}\text { Objašnjenje na } \\
\text { slovenačkom jeziku }\end{array}$ & $\begin{array}{l}\text { Prevod sa } \\
\text { srpskog na } \\
\text { slovenački }\end{array}$ & $\begin{array}{l}\text { Objašnjenje na srpskom } \\
\text { jeziku }\end{array}$ \\
\hline I vaditi & vežbati & $\begin{array}{l}\text { váditi -im nedov. (á â) } \\
\text { 1. s sistematičnim } \\
\text { ponavljanjem gibov, dejanj } \\
\text { prizadevati si postati } \\
\text { sposoben čim hitreje, bolje } \\
\text { opravljati kako dejanje, } \\
\text { dejavnost: tekmovalci } \\
\text { vadijo vsak dan; redno, } \\
\text { vztrajno vaditi; vaditi na } \\
\text { prostem; vaditi v majhnih } \\
\text { skupinah / pevski zbor vadi } \\
\text { v dvorani } \\
\text { 2. preh. s sistematičnim } \\
\text { ponavljanjem prizadevati } \\
\text { si postati sposoben čim } \\
\text { hitreje, bolje opravljati to, } \\
\text { kar izraža določilo: vaditi } \\
\text { gibe, skok; vaditi igranje } \\
\text { na klavir / vaditi pesem, } \\
\text { skladbo; vaditi poštevanko } \\
\text { 3. preh. s sistematičnim } \\
\text { ponavljanjem gibov, } \\
\text { dejanj usposabljati, } \\
\text { izpopolnjevati koga } \\
\text { v opravljanju kakega } \\
\text { dejanja, dejavnosti: učitelj } \\
\text { vadi učence za nastop; } \\
\text { vaditi pevski zbor; vaditi } \\
\text { se nastopanja; vaditi se } \\
\text { v pisanju / vaditi se v } \\
\text { potrpežljivosti / vaditi si } \\
\text { oči za razlikovanje drobnih } \\
\text { znakov / vaditi papigo } \\
\text { govoriti; psa vadi vsak } \\
\text { dan / vaditi mišice; vaditi } \\
\text { spomin uriti; prim. vajen } \\
\\
\text { Sinonimi: trenirati se, urti } \\
\text { se, delati vaje }\end{array}$ & $\begin{array}{l}\text { jemati ven, } \\
\text { jemati iz, } \\
\text { vleči iz }\end{array}$ & 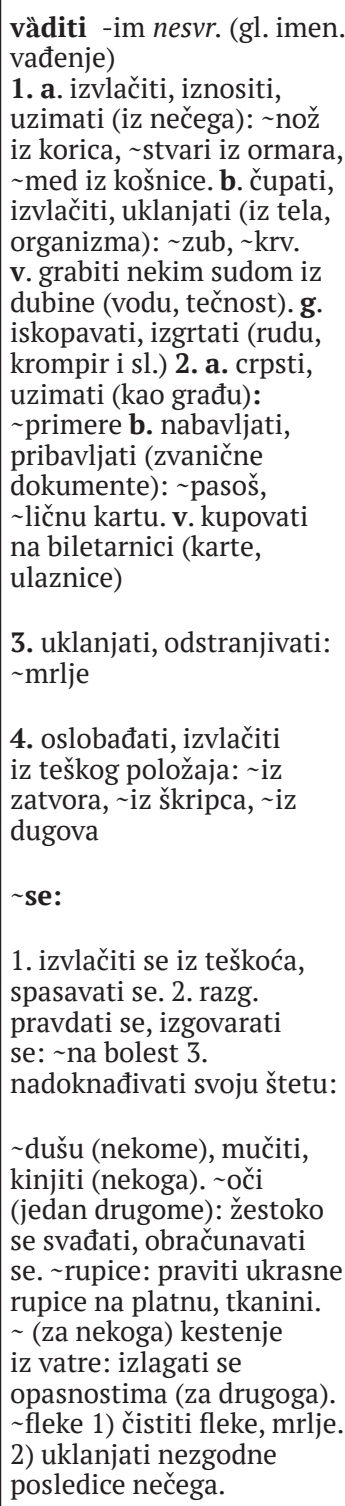 \\
\hline
\end{tabular}

Tabela 3. Predlog za odrednicu u rečniku srpsko-slovenačkih lažnih prijatelja 
Literatura

Đukanović, Vlado in Maja Đukanović. 2005. Slovenačko-srpski i srpskoslovenački rečnik. Ljubljana: Pasadena.

Đukanović, Maja. 2007. Srpsko-slovenačka međujezička homonimija. Naučni sastanak slavista u Vukove dane 36/1: 477-483.

Đukanović, Maja i Borko Kovačević. 2011. 'Problemi prevođenja sa srodnih jezika: međujezička homonimija (na primeru srpskog i slovenačkog jezika)". У Балканите: ние, сәседите, другите, 3342. Варна: Университетско издателство 'Епископ Константин Преславски".

Jurančič, Janko. 1971. Slovenački (slovenski) jezik, Gramatika slovenačkog (slovenskog) jezika za Hrvate i Srbe. Ljubljana: Državna založba Slovenije.

Kœssler, Maksim et Jules Derocquigny. 1928. Les Faux Amis ou les trahisons du vocabulaire anglais. Paris: Vuibert.

Kristal, Dejvid. 1988. Enciklopedijski rečnik moderne lingvistike. Beograd: Nolit.

Lewis, Kristian. 2008. „Dva aspekta neodređenosti pojma lažni prijatelji“. U Slavistika dnes: vlivy a kontexty, Konference mladych slavistu II,173189. Prag: Filozoficka fakulta Univerzity Karlovy v Praze, Pavel Mervart.

Mitrović, Marija. 1995. Pregled slovenačke književnosti. Novi Sad: Izdavačka knjižarnica Zorana Stojanovića.

Rečnik književnih termina. 1985. Beograd: Nolit.

Rečnik srpskoga jezika. 2011. Novi Sad: Matica srpska.

Simeon, Rikard. 1969. Enciklopedijski rječnik lingvističkih naziva. Zagreb: Matica hrvatska.

Slovar slovenskega knjižnega jezika. 2012. Ljubljana: Inštitut za slovenski jezik ZRC SAZU.

Snoj, Jerica, Martin Ahlin, Branka Lazar i Zvonka Praznik. 2016. Sinonimni slovar slovenskega jezika. Ljubljana: Založba ZRC.

Vera Majstorović

Univerza v Beogradu

Filološka fakulteta

Srbija

K SLOVARJU SRBSKO-SLOVENSKIH LAŽNIH PRIJATELJEV

Jeziki iste jezikovne skupine, kot sta na primer srbski in slovenski jezik, so genetsko sorodni in imajo številne jezikovne podobnosti. Pri komparativno-kontrastivnem jezikovnem proučevanju ugotavljamo podobnosti in razlike na morfološki, fonetični, fonološki, sintaksni 


\title{
Vera Majstorović \\ Ka rečniku srpsko-slovenačkih lažnih ...
}

in leksični ravni. $\mathrm{V}$ prispevku smo definirali, analizirali in prikazali konkretne primere slabo proučenih tako imenovanih lažnih prijateljev srbskega in slovenskega jezika. Cilj prispevka je spodbuditi nadaljnje raziskave in morebitno leksikografsko kompletiranje srbskih in slovenskih medjezikovnih homonimov.

Ključne besede: medjezikovna homonimija, lažni prijatelji, srbski jezik, slovenski jezik

\author{
Vera Majstorović \\ University of Belgrade \\ Faculty of Philology \\ Serbia
}

\section{A CONTRIBUTION TOWARDS A DICTIONARY OF SERBIAN-SLOVENIAN FALSE FRIENDS}

Languages which are part of the same linguistic family, such as Serbian and Slovenian, are genetically related and distinguished by numerous cross-lingual overlaps. Comparative-contrastive linguistic research deals with similarities and differences at the morphological, phonetic, phonological, syntactic and lexical planes. This paper explains the terminological determination of this linguistic phenomenon and offers a precise analysis of specific examples of interlingual homographs. The practical aim of the paper is to initialize new comparative and contrastive research of the two languages in contact, and also to apply the results in the fields of lexicography, language teaching, translation studies and other language-related fields.

Key words: interlingual homonymy, false friends, Serbian, Slovenian 